\title{
Efficiency of breeding value genomic assessment of Holstein stud bulls in comparison with the assessment of the offspring quality
}

\author{
Yulia Isupova ${ }^{1, *}$, Maria Kuznetsova $^{2}$, Ekaterina Gimazitdinova ${ }^{1}$, and Ekaterina Martynova ${ }^{1}$ \\ ${ }^{1}$ FSBEI of HE Izhevsk SAA, Izhevsk, Russia \\ ${ }^{2}$ Regional Breeding and Information Center, Izhevsk, Russia
}

\begin{abstract}
A comparative analysis of the genomic assessment results of Holstein breed stud bulls and their assessment on the offspring quality in the conditions of the Udmurt Republic was carried out. To analyze the efficiency of using stud bulls assessed by different methods, data from farms included in the ranking of the top 20 enterprises in terms of milk yield per cow for 2019-2020 were used. A high indicator of the complex LPI index (over 2500) was obtained in three bulls at the beginning of the assessment, by the end of the assessment there were two bulls left - J. Koln-M 11087837 and Super 64131037. The outsiders of the LPI ranking were stud bulls Parlament 52800347 and Patrik 51660096. The indicators of the complex LPI index are at a decent level for all analyzed stud bulls. It should be noted that stud bulls, which had the least change in the LPI index from April 1, 2014 to December 1, 2017, performed well. Bulls, which initially had overestimated results on this indicator, subsequently gave a sharp decline in the LPI index. The value of milk productivity of the evaluated stud bulls' daughters ranged from 5930 to $6415 \mathrm{~kg}$, the mass fraction of fat in milk from 3.79 to $4.02 \%$, protein - from 3.06 to $3.11 \%$. In most cases, the genomic assessment does not accurately reflect the change in the productive quality of stud bulls' daughters. But in the case of a predicted change to a positive or negative side in the genome, it is also confirmed by the results of assessing the offspring quality, that is, if a bull is predicted to have a sharp decrease in milk yield, then negative indicators are observed according to the "daughterpeer" method.
\end{abstract}

\section{Introduction}

To accelerate technological progress in dairy farming, widespread use of innovations is required. In this respect, breeding centers are the link that ensures a close connection between science and production, accumulating and transferring the scientists' achievements in the field of genetics and selection to the practitioners of breeding work. Interaction with these centers of breeding farms is of particular importance $[1,6,8]$.

\footnotetext{
*Corresponding author: isupova_79@mail.ru
} 
Genomic analysis is being actively introduced in the practice of livestock breeding all over the world, but in Russia this method is used only in individual cases; breeders adhere to the classical method of assessing stud bulls by daughters [3, 4, 9].

Many researchers note that the main source of genetic progress in livestock breeding is the stud bulls used in large-scale breeding programs. The introduction of genomic selection principles into the practice of domestic animal husbandry, which are the main tool for improving populations and individual herds in countries with developed animal husbandry, is of great practical importance. The offspring quality assessment used in the Russian Federation is official and final. The main disadvantage of this system is the significant time period required to obtain a result. In the conditions of 6-7 years of intensifying production processes required to assess the stud bull, the breeding composition of the herd changes 1.52 times $[2,5,6,7,10]$.

The method of genome-wide associative research makes it possible to select stud bulls at an early age, with a high degree of probability (up to $80 \%$ ); such bulls possess the qualities necessary to improve the selection characteristics of the breeding stock in domestic herds at the genetic level. In addition, the most important value of this method lies in the ability to determine undesirable genes in the genotype of a bull that negatively affect the economy of dairy and beef cattle breeding: the presence or a predisposition of genetic diseases $[5,7]$.

The purpose of this study was to analyze the offspring productivity of foreign breeding stud bulls used by enterprises of the agro-industrial complex of the Udmurt Republic and to carry out a comparative results' characterization of genomic assessment and assessment based on the "daughter-peer" method.

\section{Materials and methods}

To analyze the efficiency of using stud bulls assessed by different methods, data from farms included in the ranking of the top 20 enterprises in terms of milk yield per cow for 2019-2020 were used (according to the Ministry of Agriculture and Food of the Udmurt Republic). In the course of the work, the databases from 2010 to 2020 of the program of the RC "Plinor" "Seleks dairy cattle" were analyzed.

The object of the study was first heifers, which are descendants of holsteinized Black Pied cows and purebred Holstein stud bulls. The research included the descendants of twelve Holstein bulls imported from Canada ( 5 bulls), Germany ( 6 bulls) and France ( 1 bull) belonging to the breeding enterprises of the Udmurt Republic, Mozhgaplem LLC and SJSC Udmurtskoe for breeding work.

The paper analyzed the LPI index (Lifetime Profit Index) - the bull's lifetime profit index used in Canada.

The LPI was the first official index introduced in Canada in 1990. This index follows the introduction of the BLUP Animal Model of Canada's Bulls and Dairy Cows for performance and conformation traits: $\mathrm{LPI}=(6 \times \mathrm{PROD}+4 \times \mathrm{TYPE}) \times \mathrm{8}$, where PROD is a sub-index for performance based on fat and protein yield, TYPE is a sub-index that includes exterior characteristics that contribute to overall longevity.

The research methodology included statistical data processing using the Data Analysis package in Microsoft Excel.

\section{Results}

The selection of stud bulls based on the genomic testing results for artificial insemination is widely used by specialists in foreign countries. Selectioners of breeding organizations use seed of imported bulls. As a result, selection of young bulls obtained in local breeding farms 
has practically ceased in Russia. Over $80 \%$ of organizations have stopped custom mating. Therefore, the effectiveness study on the use of stud bulls assessed by different methods is of great importance.

Changes in the LPI index from 01.08.2014 to 01.12 .2017 for the analyzed stud bulls are presented in Tables 1-2.

Table 1. Change in the LPI index for stud bulls of LLC "Mozhgaplem".

\begin{tabular}{|c|c|c|c|c|c|c|}
\hline \multirow[b]{2}{*}{$\begin{array}{c}\text { Date } \\
\text { of genomic } \\
\text { assessment }\end{array}$} & \multicolumn{6}{|c|}{ Name and No. of the bull } \\
\hline & 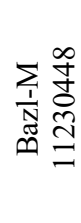 & 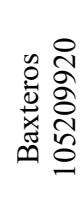 & 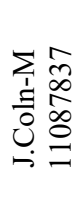 & 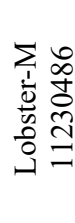 & 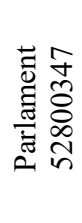 & 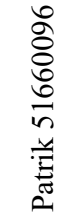 \\
\hline 01.08 .2014 & 2464 & 2473 & 2988 & 2888 & 1791 & 1831 \\
\hline 01.12 .2014 & 2359 & 2479 & 3041 & 2773 & 1818 & 1817 \\
\hline 01.04 .2015 & 2415 & 2472 & 2948 & 2774 & 1865 & 1816 \\
\hline 01.08 .2015 & 2438 & 2430 & 2925 & 2409 & 1829 & 1820 \\
\hline 01.12 .2015 & 2438 & 2425 & 2987 & 2409 & 1845 & 1818 \\
\hline 01.04 .2016 & 2436 & 2425 & 2856 & 2351 & 1881 & 1867 \\
\hline 01.08 .2016 & 2371 & 2310 & 2770 & 2252 & 1917 & 1834 \\
\hline 01.12 .2016 & 2403 & 2307 & 2777 & 2288 & 1935 & 1805 \\
\hline 01.04 .2017 & 2374 & 2301 & 2756 & 2295 & 1941 & 1786 \\
\hline 01.08 .2017 & 2383 & 2307 & 2756 & 2277 & 1944 & 1786 \\
\hline 01.12 .2017 & 2365 & 2307 & 2718 & 2259 & 1942 & 1771 \\
\hline
\end{tabular}

Table 2. Change in the LPI index for stud bulls of JSC "Udmurtskoe" for breeding work

\begin{tabular}{|c|c|c|c|c|c|c|}
\hline \multirow[b]{2}{*}{$\begin{array}{c}\text { Date } \\
\text { of genomic } \\
\text { assessment }\end{array}$} & \multicolumn{6}{|c|}{ Name and No. of the bull } \\
\hline & 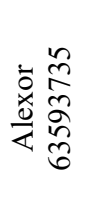 & 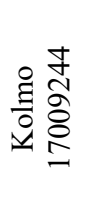 & 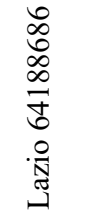 & 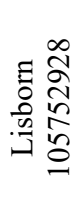 & 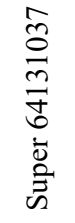 & 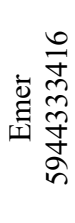 \\
\hline 01.08 .2014 & 2368 & 2142 & 2023 & 2225 & 2653 & 2473 \\
\hline 01.12 .2014 & 2369 & 2070 & 2042 & 2255 & 2619 & 2479 \\
\hline 01.04 .2015 & 2371 & 2005 & 2011 & 2242 & 2655 & 2472 \\
\hline 01.08 .2015 & 2406 & 1970 & 1951 & 2180 & 2685 & 2430 \\
\hline 01.12 .2015 & 2390 & 1931 & 1969 & 2180 & 2573 & 2425 \\
\hline 01.04 .2016 & 2353 & 1948 & 1922 & 2181 & 2730 & 2425 \\
\hline 01.08 .2016 & 2238 & 1870 & 1836 & 2190 & 2713 & 2310 \\
\hline 01.12 .2016 & 2228 & 1838 & 1824 & 2172 & 2656 & 2307 \\
\hline 01.04 .2017 & 2228 & 1783 & 1812 & 2133 & 2612 & 2301 \\
\hline 01.08 .2017 & 2234 & 1791 & 1781 & 2120 & 2569 & 2307 \\
\hline 01.12 .2017 & 2240 & 1801 & 1806 & 2138 & 2560 & 2307 \\
\hline
\end{tabular}

The genomic assessment analysis of the selected stud bulls showed that in most cases the LPI assessment for the presented period decreases with the exception of one bull - Parlament 52800347. The result of his LPI increased by 151 points, which is $7.7 \%$ of the estimate of 08.01.2014. The highest LPI indicator was recorded for the bull J. Koln-M 11087837 (01.12.2014), it amounted to 3041 points, which is $1.7 \%$ higher than the initial estimate 
(01.08.2014) and more than the last estimate $(01.12 .2017)$ by $11.8 \%$. In 2017 , the minimum indicators of this index were recorded for the bull Patrick 51660096. LPI amounted to 17711786, which was $76.9 \%$ lower than the maximum estimate among stud bulls.

It should also be noted that according to the re-evaluation results, the bull's assessment decreases due to the annual increase in the productivity of the daughters and peers of the bull, and therefore the rank of the best bulls according to the results of the first assessment changes. So, according to the results of the first assessment according to the LPI, J.Koln-M 11087837 and Lobster-M 11230486 turned out to be the best bulls, and only Zh.Koln-M 11087837 remained the leader by the fourth assessment (01.08.2015). Lobster-M 11230486 yielded according to the results of genomic assessment to Bazl-M 11230448, Baxteros 105209920, Super 64131037 and Emer 5944333416, and their superiority remained until the last reevaluation.

Of particular interest is the issue of the efficiency of using foreign breeding bulls with a genomic assessment in the farms of the Udmurt Republic (Table 3).

The discrepancy between the breeding value estimates of the same stud bulls in Canada according to the LPI system and the farms of the Udmurt Republic is mainly due to the use of different assessment methods in determining the breeding value of bulls and different conditions for animal keeping. However, it is necessary to accept that the concept of breeding value is dynamic and should be assessed regularly, at least twice a year. The foreign LPI rating system is constantly changing and changes are being made to it.

Analyzing the results of Table 3, it can be noted that Bazl-M 11230448 did not justify the predicted genetic potential. As a result of assessing the offspring quality, the milk yield of daughters decreased by $-107.62 \mathrm{~kg}$, which is less than the results of the genomic assessment by $1271.62 \mathrm{~kg}(01.08 .2014)$ and by $828.62 \mathrm{~kg}(01.12 .2017)$. The predicted result of the genomic assessment for fat varied in negative values from -0.10 to $-0.19 \%$, and as an assessment result by the classical method, positive results were obtained $+0.12 \%$.

Baxteros 105209920 fell short of the projected increase in milk yield. His genomic assessment results varied from 2009 to $1600 \mathrm{~kg}$; however, according to the results of assessing the offspring quality, a decrease in milk yield by $-28 \mathrm{~kg}$ is observed, that is, practically does not change in comparison with peers. The stud bull was assigned category B3 as a result of fat content increase in offspring milk by $0.04 \%$; however, the predicted results were in negative values and varied from -0.02 to $-0.07 \%$.

The stud bull J.Koln-M 11087837 has promising results as a result of genomic assessment. In the period from 01.08.2014 to 01.12.2017 the projected increase in milk yield was in the range from 1175 to $1492 \mathrm{~kg}$, an increase in the fat content in milk - from 0.2 to $0.39 \%$, an increase in the protein content in milk - from 0.13 to $0.22 \%$. However, as a result of assessing the offspring quality within the farms of the Udmurt Republic for 115 daughters, the indicators remain at a neutral level. There was a slight decrease in milk yield by -33.02 $\mathrm{kg}$, an increase in fat content - by $0.02 \%$.

As a result of genomic assessment, Lobster-M 11230486 also has promising results in the period from 01.08.2014 to 01.12.2017, the projected increase in milk yield varied from 1250 to $1834 \mathrm{~kg}$. However, as a result of assessing the offspring quality for 79 daughters, a decrease in milk yield by $-53.18 \mathrm{~kg}$ was recorded. In terms of the fat content in milk, this stud bull has mainly significant negative genomic scores from $0.03(01.08 .2014)$ to $-0.4(01.12 .2017)$. Based on the results of assessing the offspring quality, this stud bull was assigned to the "neutral" category.

As a result of 96 daughters analysis of Parlament 52800347, an insignificant decrease in milk yield by $-5.96 \mathrm{~kg}$ compared to their peers was revealed, which is less than the predicted genomic increase by $447.69 \mathrm{~kg}(08 / 01 / 2014)$ and by $242.69 \mathrm{~kg}(12 / 01 / 2017)$. Indicators for the fat content in milk remained in negative values both in the genomic prognosis and according to the results of assessing the offspring quality. 
Table 3. Evaluation of stud bulls by the offspring quality by different methods.

\begin{tabular}{|c|c|c|c|c|c|c|}
\hline \multirow[b]{2}{*}{$\begin{array}{c}\text { Name / inv. } \\
\text { No. }\end{array}$} & \multirow[b]{2}{*}{$\begin{array}{l}\text { Assessment } \\
\text { method }\end{array}$} & \multirow[b]{2}{*}{$\begin{array}{l}\text { Assessme } \\
\text { nt location }\end{array}$} & \multirow[b]{2}{*}{$\begin{array}{c}\text { Assessment } \\
\text { year }\end{array}$} & \multicolumn{3}{|c|}{ Breeding value by } \\
\hline & & & & $\begin{array}{c}\text { milk } \\
\text { yield, } \mathrm{kg}\end{array}$ & MFF, \% & MFP, $\%$ \\
\hline \multirow{3}{*}{$\begin{array}{l}\text { Bazl-M } \\
11230448\end{array}$} & \multirow{2}{*}{$\begin{array}{l}\text { Genomic } \\
\text { assessment }\end{array}$} & Canada & 01.08 .2014 & 1164 & -0.1 & -0.02 \\
\hline & & Canada & 01.12 .2017 & 721 & -0.17 & -0.02 \\
\hline & $\begin{array}{l}\text { By offspring } \\
\text { quality }\end{array}$ & Udmurtia & 2015-2018 & $-107,62$ & 0.12 & -0.13 \\
\hline \multirow{3}{*}{$\begin{array}{l}\text { Baxteros } \\
105209920\end{array}$} & \multirow{2}{*}{$\begin{array}{l}\text { Genomic } \\
\text { assessment }\end{array}$} & Canada & 01.08 .2014 & 1914 & -0.02 & -0.21 \\
\hline & & Canada & 01.12 .2017 & 1600 & -0.07 & -0.21 \\
\hline & $\begin{array}{l}\text { By offspring } \\
\text { quality }\end{array}$ & Udmurtia & 2016-2018 & $-28,00$ & 0.04 & 0.02 \\
\hline \multirow{3}{*}{$\begin{array}{l}\text { J.Coln-M } \\
11087837\end{array}$} & \multirow{2}{*}{$\begin{array}{l}\text { Genomic } \\
\text { assessment }\end{array}$} & Canada & 01.08 .2014 & 1492 & 0.25 & 0.17 \\
\hline & & Canada & 01.12 .2017 & 1175 & 0.21 & 0.14 \\
\hline & $\begin{array}{l}\text { By offspring } \\
\text { quality }\end{array}$ & Udmurtia & 2015-2018 & $-33,02$ & 0.02 & 0 \\
\hline \multirow{3}{*}{$\begin{array}{l}\text { Lobster-M } \\
11230486\end{array}$} & \multirow{2}{*}{$\begin{array}{l}\text { Genomic } \\
\text { assessment }\end{array}$} & Canada & 01.08 .2014 & 1834 & 0.03 & 0.03 \\
\hline & & Canada & 01.12 .2017 & 1250 & -0.4 & -0.13 \\
\hline & $\begin{array}{l}\text { By offspring } \\
\text { quality }\end{array}$ & Udmurtia & 2015-2018 & $-53,18$ & 0 & 0.03 \\
\hline \multirow{3}{*}{$\begin{array}{l}\text { Parlament } \\
52800347\end{array}$} & \multirow{2}{*}{$\begin{array}{l}\text { Genomic } \\
\text { assessment }\end{array}$} & Canada & 01.08 .2014 & 442 & -0.21 & -0.11 \\
\hline & & Canada & 01.12 .2017 & 237 & -0.26 & -0.12 \\
\hline & $\begin{array}{l}\text { By offspring } \\
\text { quality }\end{array}$ & Udmurtia & 2016-2018 & $-5,69$ & -0.06 & 0.03 \\
\hline \multirow{3}{*}{$\begin{array}{l}\text { Patrik } \\
51660096\end{array}$} & \multirow{2}{*}{$\begin{array}{l}\text { Genomic } \\
\text { assessment }\end{array}$} & Canada & 01.08 .2014 & -473 & 0.5 & 0.2 \\
\hline & & Canada & 01.12 .2017 & -719 & 0.48 & 0.19 \\
\hline & $\begin{array}{l}\text { By offspring } \\
\text { quality }\end{array}$ & Udmurtia & 2016-2018 & $-101,42$ & -0.02 & 0.02 \\
\hline \multirow{3}{*}{$\begin{array}{l}\text { Alexor } \\
63593735\end{array}$} & \multirow{2}{*}{$\begin{array}{l}\text { Genomic } \\
\text { assessment }\end{array}$} & Canada & 01.08 .2014 & 623 & 0.39 & -0.02 \\
\hline & & Canada & 01.12 .2017 & 164 & 0.45 & -0.03 \\
\hline & $\begin{array}{l}\text { By offspring } \\
\text { quality }\end{array}$ & Udmurtia & 2015-2017 & $-141,32$ & 0.02 & -0.01 \\
\hline \multirow{3}{*}{$\begin{array}{l}\text { Kolmo } \\
17009244\end{array}$} & \multirow{2}{*}{$\begin{array}{l}\text { Genomic } \\
\text { assessment }\end{array}$} & Canada & 01.08 .2014 & 912 & 0.3 & 0.06 \\
\hline & & Canada & 01.12 .2017 & 395 & 0.23 & 0.06 \\
\hline & $\begin{array}{l}\text { By offspring } \\
\text { quality }\end{array}$ & Udmurtia & 2015-2018 & $-4,48$ & 0.02 & 0.01 \\
\hline \multirow{3}{*}{$\begin{array}{l}\text { Lazio } \\
64188686\end{array}$} & \multirow{2}{*}{$\begin{array}{l}\text { Genomic } \\
\text { assessment }\end{array}$} & Canada & 01.08 .2014 & 43 & 0.36 & 0.11 \\
\hline & & Canada & 01.12 .2017 & -469 & 0.35 & 0.11 \\
\hline & $\begin{array}{l}\text { By offspring } \\
\text { quality }\end{array}$ & Udmurtia & $2015-2017$ & 21,98 & 0.05 & 0.02 \\
\hline \multirow{3}{*}{$\begin{array}{l}\text { Lisborn } \\
105752928\end{array}$} & \multirow{2}{*}{$\begin{array}{l}\text { Genomic } \\
\text { assessment }\end{array}$} & Canada & 01.08 .2014 & 803 & -0.06 & 0.04 \\
\hline & & Canada & 01.12 .2017 & 369 & -0.12 & 0.04 \\
\hline & $\begin{array}{l}\text { By offspring } \\
\text { quality }\end{array}$ & Udmurtia & 2015-2018 & 199,42 & -0.1 & 0 \\
\hline \multirow{3}{*}{$\begin{array}{l}\text { Super } \\
64131037\end{array}$} & \multirow{2}{*}{$\begin{array}{l}\text { Genomic } \\
\text { assessment }\end{array}$} & Canada & 01.08 .2014 & 1779 & -0.33 & -0.02 \\
\hline & & Canada & 01.12 .2017 & 1789 & -0.56 & -0.06 \\
\hline & $\begin{array}{l}\text { By offspring } \\
\text { quality }\end{array}$ & Udmurtia & 2015-2018 & 114,14 & -0.04 & 0.03 \\
\hline Emer & Genomic & Canada & 01.08 .2014 & 1914 & -0.02 & -0.21 \\
\hline & assessment & Canada & 01.12 .2017 & 1600 & -0.07 & -0.21 \\
\hline & $\begin{array}{l}\text { By offspring } \\
\text { quality }\end{array}$ & Udmurtia & 2016-2018 & 160,71 & 0.03 & 0 \\
\hline
\end{tabular}


Daughters of Patrik 51660096 reduced milk yield by $101.42 \mathrm{~kg}$, fat content - by $0.02 \%$ compared to their peers. Also in the period from 01.08.2014 to 01.012 .2017 , the predicted change in milk yield varied in negative values from -473 to $-719 \mathrm{~kg}$, respectively.

The stud bull Alexor 63593735 did not live up to the predicted genetic potential. As a result of assessing the offspring quality, milk yield decreased by $-141.32 \mathrm{~kg}$, which was less than the genomic estimate by $731.82 \mathrm{~kg}(01.08 .2014)$ and by $272.82 \mathrm{~kg}(01.12 .2017)$. Genetic prognosis for an increase in milk fat from 08.01.2014 to 12.01 .2017 varied from $0.39 \%$ to $0.45 \%$, and according to the results of the classical bull appraisal method it amounted $0.02 \%$, which is less than the forecast by $0.37 \%$ and $0.43 \%$, respectively.

As a result of 135 daughters analysis of Kolmo 17009244, it was revealed that there was a slight decrease in milk yield by $-4.48 \mathrm{~kg}$, which is less than the projected genomic increase by $916.48 \mathrm{~kg}(01.08 .2014)$ and $399.48 \mathrm{~kg}(01.12 .2017)$. Positive values were obtained according to the results of assessing the content of fat and protein in milk both in the genomic forecast and according to the results of assessing the offspring quality in the range from 0.01 to $0.02 \%$.

Lazio 64188686 had the following genomic assessment results: from an increase in milk yield by $43 \mathrm{~kg}(01.08 .2014)$ to a decrease by $469 \mathrm{~kg}(01.12 .2017)$. However, according to the results of assessing the offspring quality, a slight increase in milk yield by $21.98 \mathrm{~kg}$ is noticeable. By the fat content in milk in the period from 01.08.2014 to 01.12.02017 according to the results, an increase was predicted in the range from 0.35 to $0.37 \%$, and according to the results of assessing the offspring quality, recorded increase is only by $0.05 \%$.

Lisborn 105752928 is a stud bull; according to the results of evaluating the offspring quality, it showed the best result in increasing milk yield. The excess of daughters' milk yield over milk yield of peers was $199.42 \mathrm{~kg}$, which was less by $189.52 \mathrm{~kg}$ than the projected increase (01.012.2017). The assessment for the fat content in milk was confirmed and has a negative result - both in terms of genomic assessment and the offspring quality.

Stud bull Super 64131037 partially justified the forecast based on the results of the predicted change in productive indicators. The projected increase in milk yield in the period from 01.08.2014 to 01.012.2017 ranged from 1779 to $1789 \mathrm{~kg}$. A positive value was also obtained as a result of evaluating the offspring quality, the excess of daughters over their peers was $144.14 \mathrm{~kg}$. The predicted decrease in the fat content in milk for this bull was in the range from -0.33 to $-0.56 \%$, and according to the results of assessing the offspring quality, the decrease was $-0.04 \%$.

Emer 5944333416 ranks second in terms of offspring quality. The projected increase in milk yield from 01.08.2014 to 01.12.2017 is in the range from 1600 to $1914 \mathrm{~kg}$. According to the results of evaluating the offspring quality, the increase in milk yield amounted to $160.71 \mathrm{~kg}$, the fat content in milk $-0.03 \%$. However, the predicted reduction in milk fat by genomic estimates ranges from -0.02 to $0.07 \%$.

\section{Discussion}

As a result, it can be noted that in general, the results of an early foreign genomic assessment and the results of a later assessment of the offspring quality do not coincide in most cases. That is, the opposite tendency is generally observed: if a stud bull has a genome assessed by the amount of milk yield with a positive effect, then it turns out to be neutral or an impairment by the offspring quality, and by quality indicators, on the contrary, if it has a negative effect on the genome, then it is mostly evaluated as an enhancer by the offspring quality. Therefore, in order to increase the selection efficiency of stud bulls, it is necessary to create its own genetic base in the Udmurt Republic, which will be based on the domestic reference population of pedigree cattle. 


\section{Conclusion}

Thus, in most cases, the genomic assessment does not reflect the productive qualities of stud bulls' daughters assessed in this work. But at the same time, when using bulls evaluated by the genome, the best results in assessing the offspring quality were obtained from stud bulls with a high genomic rating. The level of superiority in productivity of the daughters of specific bulls, the change in the breeding value of bulls over the years since the first genomic assessment should be considered when selecting bulls.

\section{References}

1. A.I. Lyubimov, Bulletin of the Bashkir State Agrarian University, 3 (51), $52-58$ (2019)

2. E.N. Martynova, Perm Agrarian Bulletin, 1 (21), 125-131 (2018)

3. V. Mymrin, Dairy and Beef Cattle, 3, 4-7 (2012)

4. E.I. Saksa, Dairy and Beef Cattle, 1 , 5-8 (2018)

5. N.I. Strekozov, Dairy and Beef Cattle, 6, 10-13 (2018)

6. V.M. Yudin, Agrarian Bulletin of the Urals, 7 (137), 44-47 (2015)

7. A.P. Yamshchikov, Integration interactions of young scientists in the development of agricultural science: materials of the National Scientific and Practical Conference of Young Scientists, 208-214 (2020)

8. A.I. Liubimov, E.N. Martynova, Yu.V. Isupova [et al.], BIO Web of Conferences: International Scientific-Practical Conference "Agriculture and Food Security: Technology, Innovation, Markets, Human Resources” (FIES 2019), 00158 (2020)

9. E.N. Martynova, IOP Conference Series: Earth and Environmental Science, Krasnoyarsk, 72029 (2019)

10. A. Lyubimov, E. Martynova, Y. Isupova, E. Yastrebova, Digital agriculture development strategy: Proceedings of the International Scientific and Practical Conference (ISPC 2019), 258-261 (2019) 